\title{
Sales Records Based Recommender System for TPO-Goods
}

\author{
Ryosuke Saga Student Member (Osaka Prefecture University, saga@cs.osakafu-u.ac.jp) \\ Hiroshi Tsuji Member (Osaka Prefecture University, tsuji@cs.osakafu-u.ac.jp)
}

Keywords : e-Commerce, Recommender System, Information filtering, Memory-based Reasoning

There are TPO (Time, Place, and Occasion)-goods which change the own value by external factors such as time, place and occasion as the name indicates. Each of the goods commonly has three features: many attributes, multiformity, and high-frequency update.

To recommend the goods, we design the system based on the following policies: (a) the system should attach importance to individual preference than the preference of the third persons, (b) the system should make recommendation by using user's preference implied in the past sales records.

Thus, we propose an alternative recommender system as shown in Fig 1. The proposed system recommends more preferable goods than user's selected goods by using his past sales records. Additionally, for metrizing the preference not from the thirds person's information but from his sales record database, this system can make recommendation for individual without third person's preference.

Our system consists of two main components: preference metrization component and recommendation component. The former component metrizes the user's preference by using the static methods such as the goodness of test and generates preference distribution. Using the distribution, we gain the following merits: (i) comprehending the user's preferableness for goods, (ii) identifying the direction for the user to compensate the deviance, and (iii) finding the preferable goods. The latter component makes recommendation by using the selected goods and the feature of the preference distribution. The component has three recommendation methods: High-Angle Search, Low-Angle Search, and Neighbor Search. High-Angle Search makes recommendation by looking down from the apex of the preference

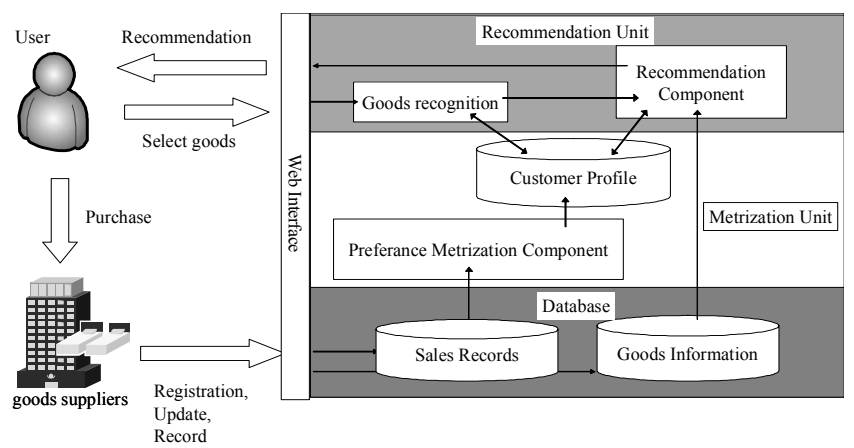

Fig. 1. Recommender System for TPO-Goods distribution. On the other hand, Low-Angle Search makes recommendation by gazing up from the point of the selected goods to the apex of the preference goods. Neighbor Search makes recommendation by looking around the point of selected goods. In the case of the latter two recommendation methods, when a user selects the goods which are far from his past choice, the recommendation methods fail to recommend desirable goods. To prevent from recommending such failure, we attempt the improvement the latter two methods by MBR with preference distribution as shown Fig. 3.

Carrying out the numerical simulation about above recommendation methods for 10,000 user's data and 400,000 sales records, we have confirmed their accuracy.

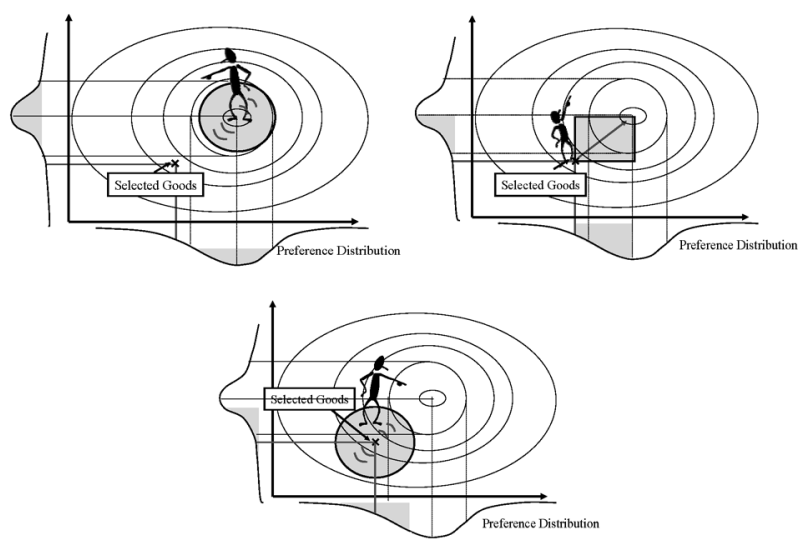

Fig. 2. Recommendation Methods

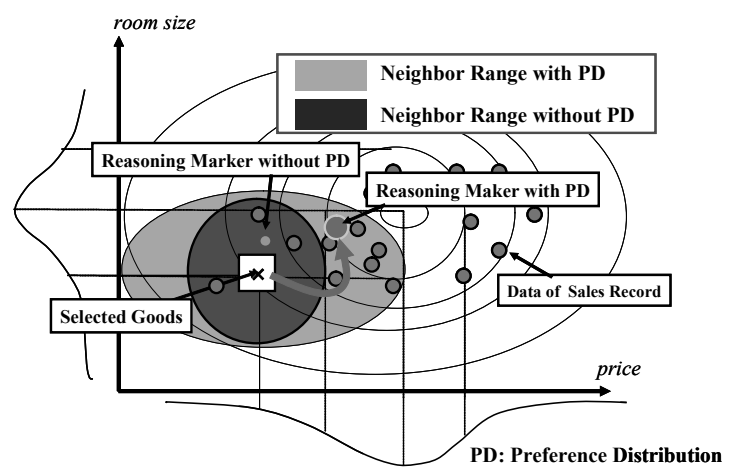

Fig. 3. Improvement of retrieve marker by MBR 


\title{
論 文
}

\section{販売履歴を用いた TPO 商品向け推薦システム}

\author{
学生員 佐賀 亮介* 正員 辻 洋*
}

\section{Sales Records Based Recommender System for TPO- Goods}

Ryosuke Saga*, Student Member, Hiroshi Tsuji*, Member

This paper presents a recommender system for TPO (Time, Place, and Occasion)-dependent goods. The TPO-dependent goods have three features: many attributes, multiformity, and high-frequency update. In order to recommend alternatives of the goods, our system (a) abstracts and metrizes the user's preference implied in sales records, and (b) filters massive alternatives by three kinds of methods: High-Angle Search, Low-Angle Search and Neighbor Search. Additionally, this paper describes the improvement method of the recommendation accuracy by memory-based reasoning with user's preference to latter two kinds of search. The numerical simulation for 10,000 user's data and 400,000 sales records has shown their accuracy.

キーワード : 電子商取引, 推薦システム, 情報フィルタリング, Memory-based Reasoning

Keywords : e-Commerce, Recommender System, Information filtering, Memory-based Reasoning

\section{1. はじめに}

情報化が一段と進むことにより，個人が扱うことのでき る情報は増加の一途をたどっている。特に Webにおいては, その発展に伴って個人の手作業では処理できないほど急激 に情報が増加し，大きな問題となっている(17)。この問題を 解決するために, 協調フィルタリングに代表される情報フ イルタリング技術が開発されてきた。そのフィルタリング 技術を実装したシステムは，情報検索におけるユーザの負 荷を軽減し, 情報選択や情報利用に関して考察するための 有意義な時間を提供することを可能にした。

電子商取引においては，それらのシステムは商品検索の 負荷を軽減させるだけでなく, ユーザへの商品推薦もまた 一つの機能として望まれており，その機能を持つシステム は Recommender System ${ }^{(11)}$ と呼ばれている。そしてそのシ ステムは, 現在 Amazon.com ${ }^{(18)}$ に代表される CD ストア, 電子書店といったオンラインショップにおいて利用されて いる。

本論文では, CD や書籍とは違う商品分類にあたる TPO (Time, Place, and Occasion) 商品(14)(15)を対象とした推薦 システムについて述べる。CD や本などはコンテンツに変化 がなく常に同じ価值を持つ一方，TPO 商品は時と場合によ りその価值が変動するという特徴を持つ。本論文の構成と

\footnotetext{
大阪府立大学大学院工学研究科

T599-8531 大阪府堺市学園町 1-1

Graduate School of Engineering, Osaka Prefecture University,

1-1 Gakuen-cho Sakai-shi, Osaka, 591-8531
}

して，まず第 2 章で TPO 商品の特性について述べ，そして 既存のフィルタリング技術を紹介しつつ TPO 商品への適用 性を分析する。第 3 章では, 2 章の分析を基にシステムを設 計し, そのシステムの構成要素である啫好の計量化と商品 推薦について述べる。第 4 章では, TPO 商品であるビジネ スホテルのデータを使って, 商品推薦手法を数值シミュレ ーションにより定量的に評価し考察する。最後に 5 章で今 後の研究課題を述べ本論を閉じる。

\section{TPO 商品とフィルタリング技術の分析}

本章では, TPO 商品の特徵について述べ, 続いて電子商 取引でよく使用されるデモグラフィックフィルタリング, コンテンツベースフィルタリング, 協調フィルタリングに ついて分析する。

〈2・1〉TPO 商品の特徵 TPO 商品(14)(15)は, 時間, 地域・場所, 場合など外部要因によって商品の価值が変わ るものである。代表例として, ビジネスホテルや飛行機チ ケットがある。その飛行機チケットはフライト日時が近づ くにつれ価格は高くなり, ホテルなどの宿泊施設は場所や 時期，イベントの有無などによって，その価值が変動する。 また, TPO 商品は次に挙げる特徴を共通して持つ。

（1）多属性 TPO 商品は商品固有の情報のみならず, 変動する情報を複数持つ。以下, 前者を固定情報, 後者を 可変情報と呼ぶ。ビジネスホテルを例に挙げれば，ホテル 名, 住所, ホテルまでの距離などが固定情報にあたり, 価 格，サービス内容などが可変情報にあたる。

（2）多様性 TPO 商品は, 各属性の組み合わせによっ 
て様々な商品が生成できる。実際，ビジネスホテルにおい ては, 各ホテルの持つ部屋の種類は平均 5 種類ほど存在し, それと価格や様々なサービスなどといった可変情報との組 み合わせを考えることにより, 平均 20 パターンもの商品が 生成されている。

(3) 高頻度更新 TPO 商品は, TPOによって商品の価 值が変わるため, $\mathrm{CD}$ や本などほぼ固定情報のみで構成され ている商品と違い更新頻度が極めて高い。そのため, まる で新商品のように生成・更新され，また時期が過ぎれば提 供されなくなる。

$\langle 2 \cdot 2\rangle$ 関連研究と要件分析 最初の Recommender System である Tapestry(5)が登場した 1992 年以降, 幅広い アプリケーションにおいて，さまざま技法が提案されてき た。その中で, デモグラフィックフィルタリング, コンテ ンツベース（内容に基づく）フィルタリング, 協調フィル タリングが各アプリケーションにおいてしばしば使われて いる。

デモグラフィックフィルタリング(7)(10)は, ユーザの年齢, 性別, 住所, 学歴, 収入, 社会的地位など, 個人情報によ ってユーザを関連付けフィルタリングを行う。そのフィル タリングを実装しているシステム例として LifeStyle Finder ${ }^{(11)}$ がある。 LifeStyle Finder は，ユーザをデモグラ フィックス情報によって 62 のクラスタに分け，そのクラス タに属するユーザの情報を元に推薦情報を生成するシステ ムである。しかしながら，このフィルタリングは，個人情 報が必要となるためにユーザの心理的抵抗に遭い, その結 果精度上昇を妨げる要因になる可能性がある(9)。また, 個人 情報を変更することが難しいために，嗜好が変化したとし ても対応できない。それ故に，この手法では十分な精度を 得ることが困難である。

一方，コンテンツベースフィルタリング(1)(4)(6)(10),(11) は, 商品に関してのユーザの評価や商品紹介などのテキストデ ータで記述された内容に基づいて, 嗜好を予測しフィルタ リングする手法である。その嗜好の予測方法は, さまざま な手法が提案されており，Fab(1)においてはユーザが好む Web ページから得た TF-IDF(Term Frequency -Inverse Document Frequency）ウエイトによって, ページの内容に ウエイトをつけることで啫好を予測し，また Syskill \& Webert $^{(9)}$ ではベイジアンネットワークを利用して単語の確 率值を求め, それを元に啫好を予測しフィルタリングを行 っている。しかしながら，この手法はキーワードを分析対 象として扱うが，価格や距離などの数值情報を扱わない。 その結果, 価格や公共交通機関からの距離といった意思決 定において, 重要な意味を持つ数值データを扱うことがで きない。仮にその数值情報をも分析対象としたとしても, TPO 商品は TPO によって価值が変化・更新されるため, その数值パターンが非常に多くなり, その結果各パターン に対して，嗜好予測に十分な情報を集めることが難しい。 実際, ビジネスホテルにおいては価格を始め, 部屋の広さ, 公共交通機関からの距離といった数值データを含んだ情報
からなり, また飛行機のチケットなどでは, 価格やサービ スの質などが TPOにより頻繁に変化する。

また協調フィルタリング(4)(5)(6)(10)(12)(16)は，似通ったユー ザ同士は互いに同じ商品を好むという前提からユーザ同士 を関連づけ，似通った第三者の啫好情報を提供することに よって商品を推薦する手法である。それを実装したシステ ムとして, Tapestry(5), GroupLens ${ }^{(12) な と ゙ か ゙ あ る 。 T a p e s t r y ~}$ は電子メールを, GroupLens は Usenetニュースや映画な どを対象にしており，それらシステムはコンテンツの中身 や添付されたメッセージを分析し, その分析を元にフィル タリングを行っている。しかしながら, TPO 商品は高頻度 で更新されることから, 更新された情報に対しての十分な 評価が集まらないといった問題がある。また, データとし て表現しにくい目に見えないサービス要素（例えば, 従業 員のサービス向上) により商品価值が変化するため, 評価 にばらつきが生じる可能性がある。前者の問題は, Cold-start 問題(16), 後者は Gray sheep 問題(4) と呼ばれ, 協 調フィルタリングが効果的に動作しない原因として Claypool ら(4)によって提言されている。このことから協調 フィルタリングもまた, TPO 商品に適用することが難しい といえる。

\section{TPO 商品向け推薦システム}

〈3・1〉 システム概要 TPO 商品は商品の価值が高頻 度で更新され, 新たに生成されるといった特徵を持つため に, 現在の商品をベースに推薦することは難しい。また, 協調フィルタリングが適用できない問題を 2 つ挙げたが, これは第 3 者の商品に対する評価に頼った推薦手法がこの 原因であると考えることができる。

そこで, これらの理由から, 我々はTPO 商品向け推薦シ ステムを以下のポリシーに基づいて設計した。

・嗜好が潜在しているトランザクションデータからユ ーザの嗜好を抽 $\mathrm{z}$ 出する。特に本論文では, トランザ クションデータとして販売履歴データベースを用い, 嗜好を抽出する。

・ 第三者・商品の評価による関連付けでのフィルタリ ングではなく, 個人の嗜好に特化した Recommender System を形成する。

そして,これらのポリシーに基づいて設計した Recommender System を図 1 に示す。このシステムは, ユ ーザが商品情報を選択したとき，ユーザの嗜好に基づいて よりふさわしい商品を推薦することを目的としており，こ のシステムでは第 3 者の情報を用いるのではなく個人の販 売履歷から啫好を予測する。それ故に, 第 3 者の評価の影 響を受けない個人の嗜好に特化した推薦システムになって いる。また, 提供商品の情報を推薦の際にのみ利用するこ とでシステムと提供商品の依存度を下げ，外部要因により 変化する商品の影響度を小さくしている。

このシステムを構成する要素として, 次に挙げるコンポ ーネントとデータベースを設けた。 
・ コンポーネント

- 商品認識コンポーネント

- 推薦コンポーネント

- 嗜好計量化コンポーネント

・ データベース

- 販売履歴データベース

- 商品情報データベース

- 顧客プロファイルデータベース

また，これらのコンポーネントとデータベースを組み合 わせた独立に稼動する系として, 推薦ユニット, 計量化ユ ニットを作成する。前者は推薦コンポーネントと商品認識 コンポーネントによって構成され, 選択商品をユーザの啫 好に基づいて認識し, 新たに商品を推薦する。後者は啫好 計量化コンポーネントと顧客プロファイルデータベースに より構成され, 統計手法を用いて販売履歴から嗜好を抽出 し計量化する。これらのユニットは顧客プロファイルデー タベースにおいて結びついており, その顧客プロファイル データベースはユーザが購入するたびに後者により更新さ れる。以降, これらのコンポーネントの動作についてより 詳細に述べる。

〈3·2〉嗜好の計量化提案システムでは, 販売履歴 データベースに統計手法を用いることにより嗜好の計量化 を行う。販売履歴情報は過去に販売された商品データと関 連づいており，これを分析することでユーザがどのような

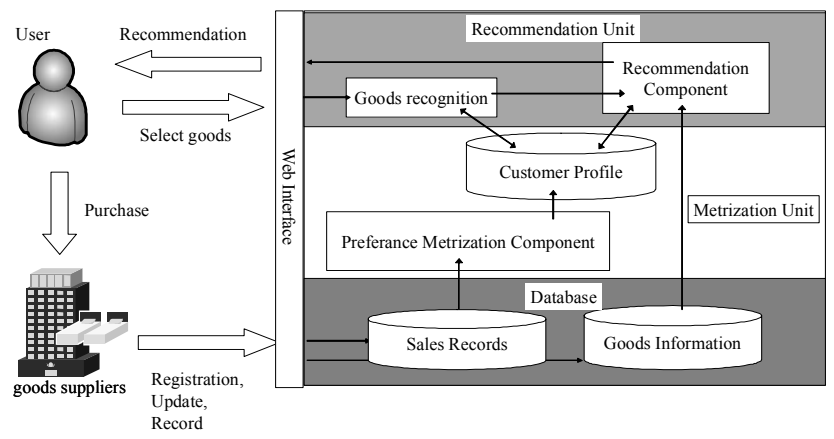

図 1 TPO 商品向け推薦システム

Fig. 1. Recommender system for TPO-goods.
商品を好むかを知ることができる。

そこで我々は，図 2 によって示される一連の流れによっ て嗜好の計量化を行う。この計量化では, まず属性ごとに 值を集計する。その属性が数值データの場合には連続型ヒ ストグラム，名義データにおいては項目ごとに集計する。

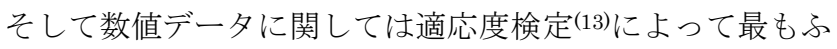
さわしい確率分布に置換し, また名義データにおいては項 目ごとに確率值を求め, 確率表を作成する。こうして求め られた確率分布・確率表において, 最もよく利用されてい る属性值が 1 となるように, 式(1)を用いることにより值を Oから 1 の間に正規化する。

$$
P_{j}(x)=\frac{f_{j}(x)}{\max f_{j}}
$$

ここで, $f_{j}$ は属性 $j$ における確率分布の確率密度関数を表 し, $f_{j}(x)$ は商品 $x$ における属性 $j$ の確率值を表す。また, max $f_{j}$ は, 確率密度関数值の最大值を示す。これにより与えられ た值を $P_{j}(x)$ を嗜好度と呼び, $P_{j}(x)$ からなる分布を嗜好分布 と呼ぶ。

以上の過程により求めた嗜好分布を使用することによっ て, 次に挙げる利点が得られる。

（1）ユーザの商品に対する嗜好を認識することができる。

(2)選んだ商品が, ユーザが最も好むものからどれほどず れているかを知ることができる。

( 3 ) 最も商品を好む状態からのずれを補正するような商 品を探し出すことができる。

特に(1)に関して, 以下の式 (2)を用いることにより定量 的に商品 $x$ に対する嗜好の認識を行う。

$$
E v(x)=\sum_{j} w_{j} P_{j}(x)
$$

ここで, $w=\left\{w_{0}, w_{1}, \ldots, w_{j}\right\}$ は各要素が最大值 1 の商品属性間 の重み比率, $P_{j}(x)$ は商品 $x$ の属性 $j$ の嗜好度を表し, これに より求まった $E V$ を商品適応度と呼ぶ。また, 後に行う数值 シミュレーションにおいて $w$ は全て 1 とする（つまり，属 性間の重みの差はないとみなす)。

〈3.3〉商品推薦技法本節では嗜好分布とその利点 を活用した, 俯瞰型推薦, 仰瞰型推薦, 近傍推薦による商 品推薦手法を述べる（図 3 ）。

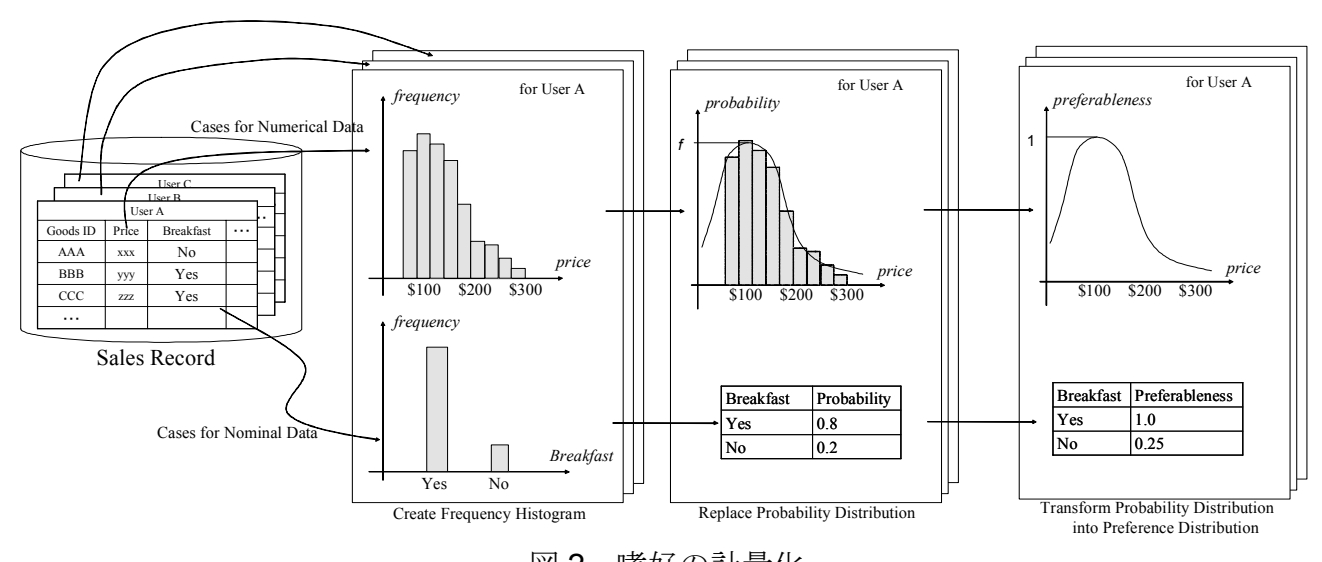

困 2 啫好の計量化

Fig. 2. Preference metrization. 


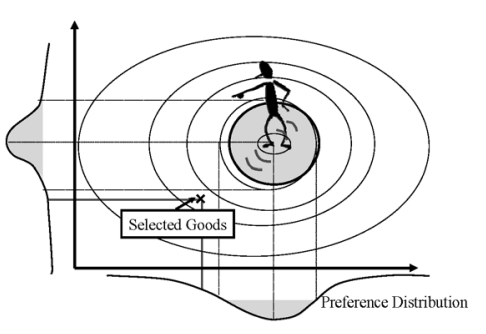

(a) High-angle search

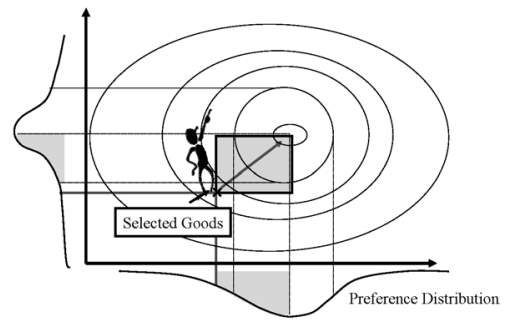

(b) Low-angle search

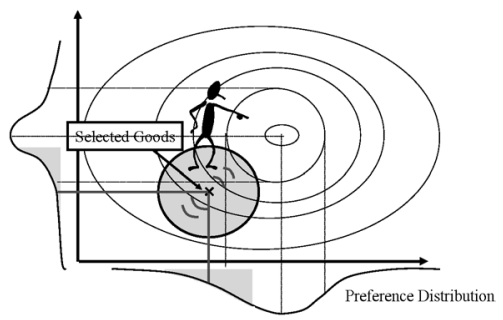

(c) Neighbor search

図 3 推薦手法

Fig. 3. Recommendation methods.

俯瞰型推薦は，嗜好分布を利用した推薦手法であり，ユ 一ザの各属性における嗜好分布の值が最大になる点（嗜好 分布の頂点）から見下ろした形で商品を探しだす手法であ る。この手法は，ユーザにとってふさわしいと思われる商 品が得られるが, 選択商品の情報, つまりユーザが今興味 を持っている商品情報が反映されないというデメリットが ある(図 $3(\mathrm{a})$ )。

一方, 仰瞰型推薦は嗜好分布と選択商品を利用し, 選択 商品を推薦起点としてそこから嗜好分布の頂点を見上げる ように商品を推薦する。この手法は, 選択商品を用いるた め推薦結果にその商品の情報が反映され，またその特徴に よって，必ず選択商品よりもユーザにとって好ましい商品 を推薦することが可能である(図 $3(\mathrm{~b}))$ 。

また, 近傍推薦は選択商品のみを利用し, 仰瞰型推薦と 同様にその商品を推薦起点とし，その付近を見渡すように 商品を探し出し推薦する手法である。この手法は, 嗜好分 布を利用せず選択商品のみを用いるため，他の推薦手法よ りも選択商品の情報が推薦結果に反映されやすく，選択商 品が嗜好分布のどの位置にあるかによって推薦商品の質が きまる(図 $3(\mathrm{c})$ )。

これら 3 手法を組み合わせることで様々な手法が提案可 能である。例えば，近傍推薦と仰瞰型推薦の探索範囲を和 結合させた場合，選択商品の情報を重視しつつ，選択商品 より好ましい商品が推薦できる。しかしながら, 後者 2 つ の推薦手法は推薦商品がユーザの選択商品に依存するため に，選択商品自体が啫好分布の頂点より離れているとき， ふさわしい商品が推薦されない可能性が高い。

そこで，選択商品を用いる仰瞰型推薦，近傍推薦におい て，販売履歴を記憶とした Memory-based Reasoning（以 下，MBR と略す）と嗜好分布を組み合わせることにより， 新たな推薦起点を頂点付近に作成し, 推薦商品の質を向上 させることを試みる。

〈3.4〉 M B R 利用した推薦起点の改善 $\quad \mathrm{MBR}^{(8)}$ は，データマイニング手法の一つであり，対象データに関 する情報を過去の記憶データとの近傍度によって推論し， 推論したものに過去の記憶を反映する。本論文では，この 手法を推薦起点変更に利用する。ただし, 対象データは選 択商品, 記憶データは販売履歴に含まれる商品データをさ す。MBR において近傍度を測る尺度として，MBR は商品
属性間の距離を用いる。その際, 各データの属性值はそれ ぞれの尺度が違うために正規化をする必要がある。そこで 今回, 式(3)によって各值を 0 から 1 に正規化し, 式(4)に よって距離を求める。

$$
\begin{aligned}
Z_{i j} & =\frac{x_{i j}-\min _{n} x_{n j}}{\max _{n} x_{n j}-\min _{n} x_{n j}} \ldots \ldots \ldots . . . . . \\
d_{i} & =\sqrt{\sum_{j} \operatorname{difference}_{j}\left(z_{i j}, z_{o j}\right)}
\end{aligned}
$$

ただし, $x_{i j}$ はデータ $i$ における属性 $j$ の值を表し, 特に $x_{o j}$ は対象データの值， $z_{o j}$ は正規化された対象データの值を表 す。そして $d_{i}$ は対象データとデータ $i$ の距離の合計を表す。 また, 式(4)における $\operatorname{difference}_{f}\left(A_{f}, B_{f}\right)$ は次の式(5)によって 与えられる。

difference $_{f}\left(A_{f}, B_{f}\right)$

$$
= \begin{cases}\left(A_{f}-B_{f}\right)^{2} & \text { (property } f \text { is numerical) } \\ 1 & \text { (property } \left.f \text { is nominal and } A_{f} \neq B_{f}\right) \\ 0 & \text { (property } \left.f \text { is nominal and } A_{f}=B_{f}\right)\end{cases}
$$

MBR には， $0 \leqq d_{i} \leqq D （ D は$ 閾值を表し，以下，この範囲 を近傍範囲と呼ぶ）を満たすデータから推論する RangeQuery 法(2) と, $d_{i}$ の下位 $k$ 個のデータを用いて推論す る $k$-Nearest Neighbor 法(2)(3),(8)がある。本研究では, RangeQuery 法を用い, 式(4)によって全てのデータの距離 を求めた後, 次の式( 6 )によって新たなデータ $y$ を推論する。

$$
y_{j}=\frac{1}{k} \sum_{n=1}^{k} X_{n j} \quad X=\left\{x_{i j} \mid 0 \leq d_{i} \leq D\right\}
$$

ただし， $y_{j}$ は新たに推論されたデータ $y$ の属性 $j$ の值, $k$ は 集合 $X$ の個数を表す。

以上の過程により求めた推薦起点は, MBR の近傍探索と いう性質上，対象データと似たものになる。また，ユーザ の嗜好が組み込まれていないために，対象データが嗜好分 布の頂点から離れている際, 推薦起点もまた同様の結果と なる可能性がある。そこで，ユーザの嗜好を反映するため に, 式(4)に嗜好度と商品属性間の重みを掛け合わせた式 (7)を用いて推論にバイアスをかける。

$$
d_{i}=\sqrt{\sum w_{j} P_{j}\left(x_{j}\right) \text { difference }_{j}\left(z_{i j}, z_{o j}\right)} \ldots
$$

これにより，たとえユーザが商品適応度の低い商品を選 


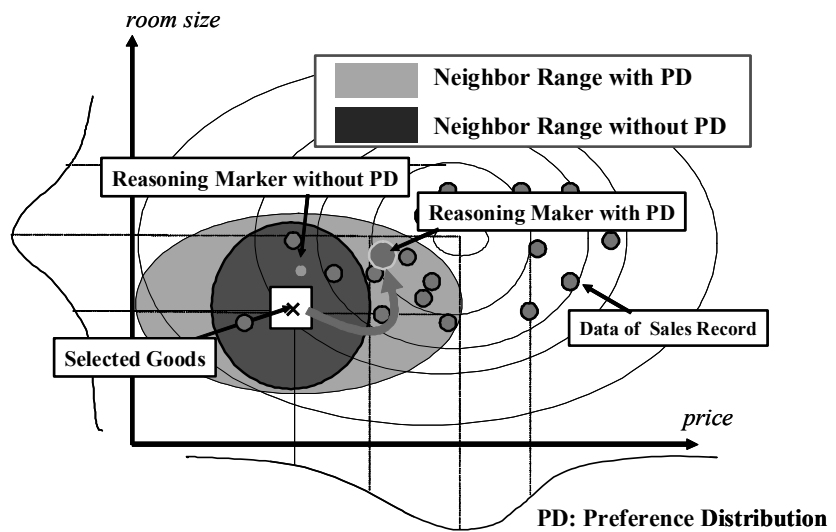

図 4 MBR による推薦起点の改善

Fig. 4. Improvement of retrieve marker by MBR.

んだとしても，嗜好度が低い属性軸（図 4 における横軸） に関して近傍範囲を相対的に拡大寸ることにより，嗜好分 布の頂点に近いデータを近傍範囲に含めることが可能にな る。つまり，ユーザの嗜好を考慮した推薦起点の変更が可 能になる。

\section{4. シミュレーション}

〈4·1〉 シミュレーション概要＼cjkstart本シミュレーション では, TPO 商品のひとつであるビジネスホテルに関して, 実データを用いて 3 章で述べた各推萀手法の数值検証を行 う。ビジネスホテルは，2 章で述べた TPO 商品の特徵を全 て満たしており，そのデータはシミュレーションとして用 いるのにふさわしい。そこでこのデータを用いて，まず(a) 俯瞰型推薦, 仰瞰型推薦, 近傍推䳸の各推薦手法について シミュレーションを行い, 続いて, 後者 2 つの推薦手法に 関して(b)MBR を利用した場合におけるシミュレーション， (c)MBR での嗜好分布を付加した場合におけるシミュレー ションを行う。ただし，MBR における RangeQuery 法の䦨 值は 0.05 とする。

このシミュレーションで使用するデータとして，ユーザ 約 10,000 人分の 2000 年 7 月から 2004 年 4 月までに購入 した販売履歷 400,000 件のデータを用いた。これらのユー ザの販売またパラメータとして，商品属性は，価格，部屋 の広さ，公共交通機関からの距離，朝食サービスの有無を 用いた。ここで, そのパラメータに属した嗜好分布を作成 する際, 初期の購買と最新の購買を独自に分析した結果, ユーザの嗜好が変化していることがわかった。そこで，嗜 好分布は各ユーザの最新購買データ 20 件分を用いることで 作成した（ただし， 20 件は著者らが分析した結果、全ての ユーザが嗜好分布を確実に作成できる最小の件数である)。 また、ユーザの販売履歴データから擬似商品データを作成 し，それを評価データとして用いた。

本シミュレーションにおける評価指標として, 商品適応 度と推薦精度を用いる。推薦精度は, 各手法がその評価デ ータの評価值よりもよいものをもつ商品を, 推薦した全商 品の何割推薦できたかを評価することで行う。
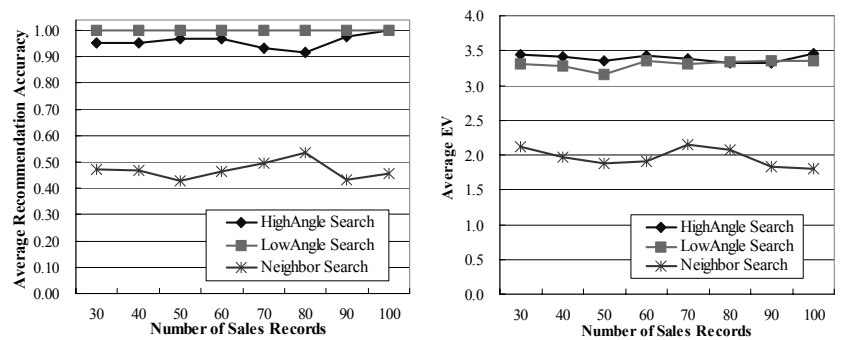

(a) Simulation for three recommendation methods
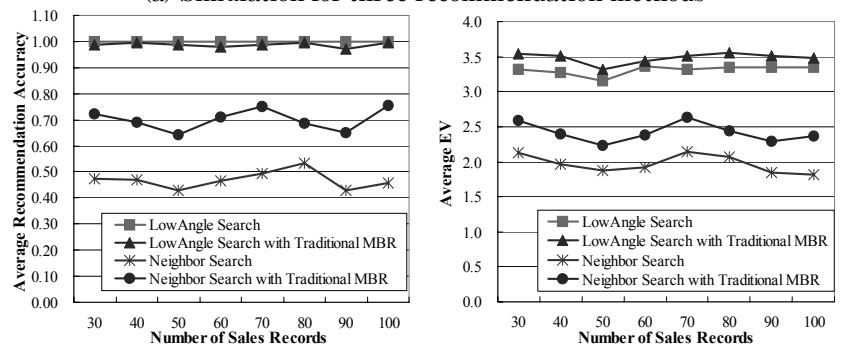

(b) Simulation for evaluating traditional MBR
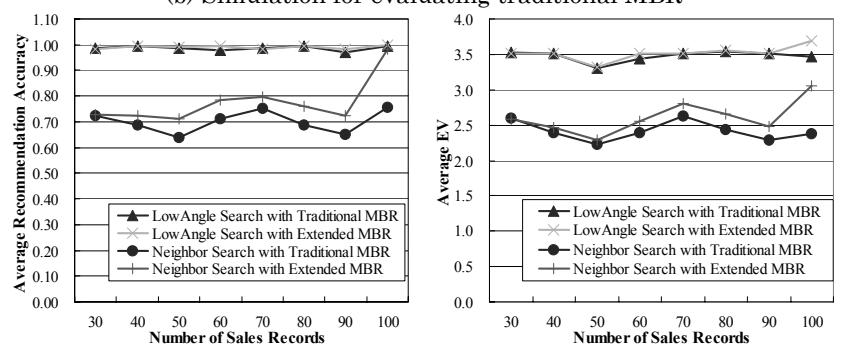

(c) Simulation for evaluating traditional MBR and extended MBR

図 5 シミュレーション結果

Fig. 5. Simulation results.

〈4·2〉 結果と考察シミュレーションした結果を図 5 に示す。図 5 において横軸には販売履歴をとり, 縦軸には 商品適応度もしくは推薦精度をとる。ただし, Extended MBR は本論において提案した MBR 手法を示す。

最初のシミュレーション結果である図 5(a)において, 俯 瞰型推薦, 仰瞰型推葴, 近傍推萀を比較したとき, 前者 2 つの手法は共に, 推薦精度, 商品適応度において高い評価 值を指していることが確認できた。しかしながら，近傍推 薦はそれに及ばず，仰瞰型推薦，俯瞰型推薦の 5 割ほどの 值にとどまっている。これらの大きな違いは，嗜好分布を 用いているかどうかであり，嗜好分布を用いたことが評価 值に大きく影響を与えていると推測できる。

続いて嗜好分布を付加していないMBR を使用した場合，

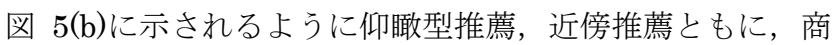
品適応度, 推萀精度の上昇が確認できた。特に近傍推薦に おいて, 推薦精度は 2 割ほどの向上が見られた。

最後に嗜好分布を付加した MBR を用いたシミュレーシ ョンでは, 図 5(c)に示されているように先のシミュレーショ ンよりも評価值が向上していることが確認できた。仰㒈型 推薦においては商品適応度においてほとんどの場合におい て最も高い值を示しており, 近傍推薦においては商品適応 度, 推薦精度ともに嗜好分布を付加する前より高い評価値 を示している。また近傍推薦において, 販売履歴が増加す 
るに従って僅かながら推薦精度が増加する傾向が確認でき た。これは, 嗜好を考慮した MBRによる推薦起点の改善が, 履歴データが多くなるにつれてより効果的に働いており, 推荗精度が推薦起点の影響を受ける近傍推薦に表れている ことを示していると我々は考察した。

\section{5. おわりに}

本論文では, 販売履歴を用いた TPO 商品向け推薦システ ムについて述べた。まず TPO 商品の特徵である多属性, 多 様性, 高頻度更新について述べ, 従来のフィルタリング技 術を適用した時に考えられる問題点を明確にした。そして, (1)販売履歴を元に嗜好を予測する，(2)第三者との関連より も，個人の嗜好に特化した推薦を行う，という 2 つのポリ シーに基づいてシステムを設計した。そのシステムは，統 計手法による嗜好の計量化手法と嗜好分布を用いた俯瞰型 推茂, 仰瞰型推薦, 近傍推薦の 3 通りの推薦手法を基盤に 成り立っている。特に, 推薦手法における後者 2 つの推薦 手法においては, MBR に嗜好分布を付加させることにより 推薦精度を改善させる手法を提案した。提案手法の数值検 証シミュレーションでは, 各推薦手法の特徵が確認でき, また MBRによる改善も確認できた。

本論文において, 啫好分布を用いることによって TPO 商 品の推薦を行った。しかしながら, 十分な量の販売履歴デ 一タがない時に嗜好分布が作成できない, 商品属性間の重 み抽出についてまだ対処しきれていないといった問題が残 る。ここで，ユーザの意思決定は購買時における参照して いるWeb ページや商品情報を元に行っていることを考慮す ると, その行動履歴にはユーザの嗜好が何らか含まれてい ることがわかる。そこで次なる研究の発展として, 販売履 歴だけでなくユーザの行動を収集することにより，嗜好分 布作成に必要なデータを補い, 商品属性間の重夕抽出機能 をつけたいと考えている。

\section{謝 辞}

本論文のために，個人情報を保護すべく匿名に加工した 上で販売履歴に関するデータを利用する機会を頂いた，

（株）ベストリザーブ CEO の小野田純氏に感謝する。

(平成 17 年 4 月 4 日受付, 平成 17 年 8 月 12 日再受付)

\section{文献}

(1) M. Balabanovic and Y. Shoham : "Fab: Content-Based, Collaborative Recommendation", Commun. of the ACM, Vol.40, No.3, pp.66-72 (1997)

(2) B. Braunmueller, M. Ester, H.-P. Kriegel, and J. Sander : "Multiple Similarity Queries: A Basic DBMS Operation for Mining in Metric Databases", IEEE Trans. on Knowledge and Data Eng., Vol.13, No.1 (2001)

(3) S. Cost and S. Salzberg: "A weighted nearest neighbor algorithm for learning with symbolic features”, Machine Learning, Vol.10, pp.57-78 (1993)

(4) M. Claypool, A. Gokhale, T. Miranda, P. Murnikov, D. Netes, and M. Sartin : "Combining content-based and collaborative filters in an online newspaper", Proc. of the ACM SIGIR '99 Workshop on Recommender Systems: Algorithms and Evaluation, Berkeley,
California (1999)

(5) D. Goldberg, D. Nichols, D. Gupta, and C. Perkins : "Using collaborative filtering to weave an information Tapestry", Commun. of the ACM, Vol.35, No.12, pp.61-70 (1992)

(6) Z. Huang, W. Chung, and H. Chen : "A Graph Model for E-Commerce Recommender Systems", J. of The American Society for Information Science and Technology, Vol.55, No.3, pp.259-274 (2004)

(7) B. Krulwich : "LIFESYLE FINDER: Intelligent User Profiling Using Large-Scale Demographic Data", Artificial Intelligence Magagine, Vol.18, No.2, pp.37-45 (1997)

(8) K. Maeda and Y. Yaginuma : "A Memory-based Reasoning Applicable to Business Problems", The Japanese Society for Artificial Intelligence, Vol.19, No.1, pp.20-27 (2004)

(9) M. J. Pazzani and D. Billsus : "Learning and revising user profiles: The identification of interesting Web sites", Machine Learning, Vol.27, pp.313-331 (1997)

(10) M. J. Pazzani : "A Framework for Collaborative, Content-Based and Demographic Filtering", Artificial Intelligence Review, Vol.13, No.5, pp.393-408 (1999)

(11) P. Resnick and H. Varian : "Recommender System", Commun. of the ACM, Vol.40, No.3, pp.56-58 (1997)

(12) P. Resnick, N. Iacovou, M. Suchak, P. Bergstrom, and J. Riedl : "GroupLens: An Open Architecture for Collaborative Filtering of Netnews", Proc. of Conference on Comput. Supported Cooperative Work (CSCW'94), Chapel Hill, NC, ACM Press, pp.175-186 (1994)

(13) J. L. Romeu : "Anderson-Darling: A Goodness of Fit Test for Small Samples Assumptions", RAC START, Vol.10, No.5 (2003)

(14) R. Saga and H. Tsuji : "Alternative Goods Recommender by Customer's Context -Example for Business Hotel Room Reservation-", Proc. of The Third International Conference on Active Media Technology, pp.331-334 (2005)

(15) R. Saga, H. Tsuji, and J. Onoda : "Agent System for Notifying Hotel Room Reservation Alternatives", Proc. of 11th International Conference on Human-Computer Interaction, USA (2005) (in CD-ROM)

(16) A. I. Schein, A. Popescul, and H. Lyle : "Methods and Metrics for Cold-Start Recommendations", Proc. of the 25th Annual International ACM SIGIR Conference on Research and Development in Information Retrieval(SIGIR2002), pp.253-260, Tampere, Finland (2002)

(17) C. Shapiro and H. Varian : Infomation Rules, Harvard Business School Press (1998)

(18) R. Spector : Amazon.com, get big fast, Harpercollins (2000)

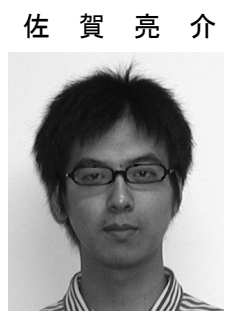

(学生員) 1980 年生。 2003 年 3 月大阪府立大 学卒業。2005 年同大学院工学研究科電気・情 報系専攻博士前期課程修了。同年同博士後期課 程入学。2005 年電子・情報・システム部門研 究会優秀論文発表賞受賞。現在, サプライチェ ーンマネジメント, エージェントシステム, ナ レッジマネジメントなどの研究に従事。

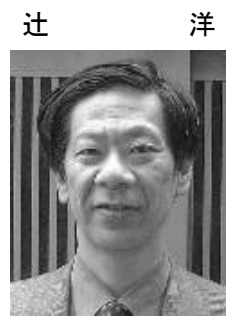

(正員) 1953 年生。1976 年京都大学工学部数 理工学科卒業。1978 年同工学研究科数理工学 専攻修士課程修了。同年(株)日立製作所入社。 1987 1988 年, 米国 Carnegie-Mellon University 客員研究員。現在, 大阪府立大学大学院工 学研究科電気・情報系専攻教授。博士 (工学), 技術士 (情報工学)。現在経営情報システム, 電子商取引, 知識管理, 意思決定支援システム などの研究に従事。IEEE, ACM, 情報処理学会, システム制御情 報学会等会員。 